\title{
Erratum to: Inhibition of human Kv3.1 current expressed in Xenopus oocytes by the toxic venom fraction of Androctonus australis hector
}

\author{
Amani Cheikh $\cdot$ Rym Benkhalifa $\cdot$ Zied Landoulsi • \\ Imen Chatti $\cdot$ Mohamed El Ayeb
}

Published online: 24 September 2014

(C) The Pharmaceutical Society of Korea 2014

\section{Erratum to: Arch. Pharm. Res.}

\section{DOI 10.1007/s12272-013-0176-5}

Unfortunately, the original version of the article contains a few errors.

These errors should be corrected as follows:

1. The authors would like to add a comment that Amani Cheikh and Rym Benkhalifa have equally contributed to this work.

2. The affiliation of the author Imen Chatti has been updated in this erratum.

3. One more colleague is added in the Acknowledgement section. The correct text is shown below.
Acknowledgments Thanks are addressed to Professor Hechmi Louzir, General Director of Pasteur Institute for constant encouragements. The authors thank Dr. Zakaria Belasfer, for taking care of animals and providing us venom; Dr. Najet Srairi-Abid for kindly providing KAah1 and KAah2; Thouraya Chagour, for venom filtration. Dr. Romain Guinamard, professor in the University of Caen, for his valuable remarks and Salaheddine Mnasri for English corrections. This work was supported by Pasteur Institute, the Ministry of Public Health and the Ministry of Research and Development (Imvt).

The online version of the original article can be found under doi:10.1007/s12272-013-0176-5.

A. Cheikh $(\bowtie) \cdot R$. Benkhalifa $(\square) \cdot$ Z. Landoulsi ·

M. El Ayeb

Laboratoire des Venins et Molécules Thérapeutiques, Institut

Pasteur de Tunis, BP 74, 1002 Tunis, Tunisia

e-mail: ameni.cheikh@pasteur.rns.tn

R. Benkhalifa

e-mail: rym.benkhalifa@pasteur.rns.tn

Present Address:

I. Chatti

Laboratory of Human Cytogenetics, Molecular Genetics and

Reproductive Biology, Farhat Hached University Hospital,

Street Ibn Eljazzar, 4000 Sousse, Tunisia 